\title{
Phytoremediation Potential of Selected Energetic Plants (Miscanthus giganteus L. and Phalaris arundinacea L.) in Dependence on Fertilization
}

\author{
Karolina Rosikon, Krzysztof Fijalkowski and Malgorzata Kacprzak \\ Institute of Environmental Engineering, Czestochowa University of Technology, Czestochowa 42-200, Poland
}

\begin{abstract}
This paper present the influence of fertilization in cultivation Miscanthus giganteus L. and Phalaris arundinacea L. in the process of phytoremediation of $\mathrm{Cd}, \mathrm{Ni}$ and $\mathrm{Zn}$. Research show that after first year of vegetation, $\mathrm{Cd}\left(0.344 \mathrm{mg} \cdot \mathrm{kg}^{-1} \mathrm{dry} \mathrm{mass} \mathrm{(d.m.))}\right.$ and $\mathrm{Zn}\left(29.47 \mathrm{mg} \cdot \mathrm{kg}^{-1} \mathrm{~d} . \mathrm{m}\right.$.) were the most absorbed metals by the biomass of Miscanthus giganteus L. grown on soil fertilized with municipalsludge (OW). However, in the case of the reed canary grass, the correlation can be attributed to the Ni $\left(3.76 \mathrm{mg} \cdot \mathrm{kg}^{-1} \mathrm{~d} \cdot \mathrm{m}\right.$.) and $\mathrm{Zn}\left(122.6 \mathrm{mg} \cdot \mathrm{kg}^{-1} \mathrm{~d} . \mathrm{m}\right.$.). In turn, after the second year of vegetation, all of the tested metals are characterized by a lower absorption as compared to the first year. In the case of reed canary grass, $\mathrm{Cd}$ and $\mathrm{Zn}$ content in the biomass after the second year of vegetation was similar to the control, while the Ni concentration was lower in relation to the control. In the case of Miscanthus giganteus $\mathrm{L}$., it was observed that the concentration of $\mathrm{Ni}$ and $\mathrm{Zn}$ in the biomass after the second year of vegetation was similar to the control, while the Cd content varied in dependence on the applied fertilizer.
\end{abstract}

Key words: Phytoremediation, energy crops, fertilization.

\section{Introduction}

Environmental contamination with heavy metals is becoming more and more serious problem. It results from continuous industrialization, which leads to the distortion of natural biogeochemical cycles. Heavy metals, in contrast to the organic pollutants are generally non-biodegradable and thus accumulate in the environment, which is a serious threat to both the environment and human health. In soil, heavy metals cause toxicological effects on soil microbes, which may lead to a decrease in their numbers and activities. Therefore, the purification of soil with heavy metals is necessary in order to minimize their impacts on ecosystems. This is an extremely difficult task considering the efficiency and technical considerations processes. There are many of physical, chemical and biological properties used for the purification of soil contaminated by heavy metals.

Corresponding author: Krzysztof Fijalkowski, Ph.D., main research field: phytoremediation.
However, conventional methods face many limitations such as high cost, intensive work, irreversible changes in soil or disturbance of native soil microflora. This is why the method of treatment will be cost-effective, environmentally friendly and most importantly efficient. One such method is phytoremediation, which is considered as a green alternative to solve the problem of heavy metal contamination [1-4].

Phytoremediation is limited by small yields of biomass and a shallow root system [5-7]. Therefore, more and more attention has been given in recent years to plants with high biomass yield. Although these plants absorb rather average amounts of metals, the total amount of the metals concentrated in the biomass yield might be comparable or even higher than in hyperaccumulators. The group of plants that can be successfully used in phytoremediation includes energy crops such as Miscanthus giganteus L. (miscanthus) and Phalaris arundinacea L. (reed canary grass). These plants are perennial, classified as herbaceous and fast growing plants that exhibit high 
biomass yield and are characterized by a very well developed root system, which is very advantageous from the stand point of phytoremediation [8-11].

Miscanthus giganteus $\mathrm{L}$. is a perennial plant having a strong, $2.5 \mathrm{~m}$ root system and thick, stiff, filled with a spongy core stems with a length of $200-300 \mathrm{~cm}$. This plant is characterized by very efficient photosynthesis process, which causes a large increase in biomass of $25 \mathrm{t} \cdot \mathrm{ha}^{-1}$ to $35 \mathrm{t} \cdot \mathrm{ha}^{-1}$. Miscanthus giganteus L. has no high demands on the quality and fertility of the soil, but tolerated $\mathrm{pH}$ in the soil is in the range 5.5-7.5. Miscanthus giganteus $\mathrm{L}$. is a species well-suited for the phytoremediation. Research shows that in the aerial parts, it accumulates the largest quantities of $\mathrm{Zn}, \mathrm{Cd}$ and $\mathrm{Cu}$. In turn, the roots are of $\mathrm{Pb}$ and $\mathrm{Ni}$. This species can also be used in phytoremediation of soils contaminated with Cr $[8,12,13]$.

Phalaris arundinacea $\mathrm{L}$. is a perennial bunchgrass of the family Poaceae, reaching a height of 1-3 m. Reed canary grass has a highly developed root system with a long horizontal stems growing below the soil surface. This plant has no high demands on the quality of the soil, but does not tolerate salinity. The optimal $\mathrm{pH}$ for growth of this species is in the range 7.7-8.2. Reed canary grass can be used in phytoremediation of soils degraded by heavy metals. Research shows that this species is well suited for the treatment of contaminated soil with $\mathrm{Zn}$, and in the case of soils contaminated with $\mathrm{Cd}, \mathrm{Cu}$ and $\mathrm{Pb}$ treatment is inadequate $[8,14]$.

In addition, cultivation of energy crops on degraded lands are desirable direction in development, since apart from reclamation, they might also be used for energy generation. This aspect is very important because of the need for development of energy obtained from renewable sources. In order for Poland to comply with the provisions of the EU's energy policy, the country is obliged to increase production of renewable energy from about $6 \%$ to $15 \%$ by 2020 [15-19].
This paper presents the influence of fertilization in cultivation Miscanthus giganteus L. and Phalaris arundinacea $\mathrm{L}$. on the process of phytoremediation of $\mathrm{Cd}$, Ni and Zn.

\section{Material and Methods}

\subsection{Container Experiment}

Twelve containers with volume of $240 \mathrm{~L}$ were used in the experiment. Each of them contained soil samples from the area of impact of the Częstochowa steelworks (Poland, Silesia region). The granulometric data indicated that the soil was medium sandy loam. Physicochemical characteristics of the soil used in the experiment are shown in Table 1.

In order to fertilize the soil with a sediment substrate, the top layers of soil from eight containers were mixed with the sewage sludge which accounted for $10 \%$ by weight. The soil in the first four containers was mixed with the sewage sludge from municipal wastewater treatment (OW), while the content of the other four was added the sludge from industrial wastewater treatment (OJ). The remaining four containers were controls. The content of heavy metals in the sewage sludge used in the experiment is shown in Table 1. After preparation, the containers were left for two weeks in order to ensure the geochemical equilibrium. After this time, the mixtures of soil with sewage sludge were used for planting Miscanthus giganteus L. (six containers, five cuttings per container), and Phalaris arundinacea L. (reed canary grass) (six containers, $20 \mathrm{~kg} \cdot \mathrm{ha}^{-1}$ per container). During the second vegetation period, foliar mineral fertilization with nitrogen was carried out with the doses of $60 \mathrm{~kg} \mathrm{~N} \cdot \mathrm{ha}^{-1}$ in Miscanthus giganteus L. and $80 \mathrm{~kg} \mathrm{~N} \cdot \mathrm{ha}^{-1}$ in reed canary grass.

The container experiment was conducted in semi-natural conditions from May 2011. The results presented in this paper relate to two vegetation periods (May 2011-November 2012) with the average temperature of $13.8^{\circ} \mathrm{C}$. The plants were watered with tap water in order to maintain adequate water conditions. 
Table 1 Characteristic of soil and sewage sludge used in experiment.

\begin{tabular}{|c|c|c|c|}
\hline Parameter & Value & & Average \\
\hline \multicolumn{4}{|l|}{ soil } \\
\hline $\mathrm{pH}$ in $\mathrm{H}_{2} \mathrm{O}$ & \multicolumn{2}{|l|}{-} & $7.88 \pm 0.01$ \\
\hline $\mathrm{pH}$ in $1 \mathrm{M} \mathrm{KCl}$ & \multicolumn{2}{|l|}{-} & $7.4 \pm 0.01$ \\
\hline CEC (cation exchange capacity) & \multicolumn{2}{|l|}{$\mathrm{cmol} \cdot \mathrm{kg}^{-1}$ d.m. } & $19 \pm 0.14$ \\
\hline $\mathrm{C}$ & \multicolumn{2}{|l|}{$\mathrm{mg} \cdot \mathrm{kg}^{-1}$ d.m. } & $17,450 \pm 0.95$ \\
\hline $\mathrm{N}$ & \multicolumn{2}{|l|}{$\mathrm{mg} \cdot \mathrm{kg}^{-1}$ d.m. } & $481 \pm 4.9$ \\
\hline $\mathrm{P}$ & \multicolumn{2}{|l|}{$\mathrm{mg} \cdot \mathrm{kg}^{-1}$ d.m. $\mathrm{P}_{2} \mathrm{O}_{5}$} & $15 \pm 1.4$ \\
\hline $\mathrm{Cd}$ & \multicolumn{2}{|l|}{$\mathrm{mg} \cdot \mathrm{kg}^{-1}$ d.m. } & $2.3 \pm \mathbf{0 . 3 3}$ \\
\hline $\mathrm{Cr}$ & \multicolumn{2}{|l|}{$\mathrm{mg} \cdot \mathrm{kg}^{-1}$ d.m. } & $26.32 \pm 2.83$ \\
\hline $\mathrm{Cu}$ & \multicolumn{2}{|l|}{$\mathrm{mg} \cdot \mathrm{kg}^{-1}$ d.m. } & $29.44 \pm 0.01$ \\
\hline $\mathrm{Ni}$ & \multicolumn{2}{|l|}{$\mathrm{mg} \cdot \mathrm{kg}^{-1}$ d.m. } & $28.99 \pm 1.7$ \\
\hline $\mathrm{Pb}$ & \multicolumn{2}{|l|}{$\mathrm{mg} \cdot \mathrm{kg}^{-1} \mathrm{~d} \cdot \mathrm{m}$} & $46.57 \pm 5.25$ \\
\hline $\mathrm{Zn}$ & \multicolumn{2}{|l|}{$\mathrm{mg} \cdot \mathrm{kg}^{-1}$ d.m. } & $112.0 \pm 9.83$ \\
\hline \multicolumn{4}{|l|}{ Sewage sludge } \\
\hline Metal & Value & OW & OJ \\
\hline $\mathrm{Cd}$ & $\mathrm{mg} \cdot \mathrm{kg}^{-1}$ d.m. & $6.07 \pm 0.46$ & $0.363 \pm 0.06$ \\
\hline $\mathrm{Cr}$ & $\mathrm{mg} \cdot \mathrm{kg}^{-1} \mathrm{~d} \cdot \mathrm{m}$ & $341 \pm 3.4$ & $90.6 \pm 0.3$ \\
\hline $\mathrm{Cu}$ & $\mathrm{mg} \cdot \mathrm{kg}^{-1} \mathrm{~d} \cdot \mathrm{m}$ & $293.4 \pm 1.41$ & $61.6 \pm 3.6$ \\
\hline $\mathrm{Ni}$ & $\mathrm{mg} \cdot \mathrm{kg}^{-1} \mathrm{~d} \cdot \mathrm{m}$ & $116.9 \pm 0.99$ & $18.3 \pm 0.46$ \\
\hline $\mathrm{Pb}$ & $\mathrm{mg} \cdot \mathrm{kg}^{-1}$ d.m. & $153.8 \pm 3.5$ & $25.4 \pm 0.08$ \\
\hline $\mathrm{Zn}$ & $\mathrm{mg} \cdot \mathrm{kg}^{-1} \mathrm{~d} . \mathrm{m}$. & $2,578 \pm 2.83$ & $299.2 \pm 5.3$ \\
\hline
\end{tabular}

\subsection{Methodology}

Research material consisted of plant biomass samples collected from 12 containers after the growing season. The aerial parts of plants were cut at the height of $5 \mathrm{~cm}$ above the soil, and then the plants were counted, measured and weighed. After drying, the plant material was ground in an electric grinder.

Soil samples were analyzed for $\mathrm{pH}, \mathrm{CEC}$, total carbon, total $\mathrm{N}$ and available $\mathrm{P}$. The $\mathrm{pH}$ values $(\mathrm{pH}$ in $\mathrm{H}_{2} \mathrm{O}$ and $\mathrm{pH}$ in $1 \mathrm{M} \mathrm{KCl}$ ) were measured by means of the $\mathrm{pH}$-meter Elmeton CPO-401 according to PN-ISO 10390:1997. Cation Exchange Capacity (CEC) was measured using the Kappen method [20]. Total Carbon (TC) was determined after dry combustion in the Analyzer Multi N/C 2100S according to PN-ISO 10694:2002. Total N was measured using the Kjeldahl method by means of BUCHI Digestion Unit K-435 and BUCHI Distillation Unit K-355 according to PN-ISO 11261:2002. Available P was measured using the method of Egner-Rieham by means of DR/4000V Spectrophotometer HACH according to
PN-R-04023:1996.

In order to determine total heavy metals $(\mathrm{Cd}, \mathrm{Cr}, \mathrm{Cu}$, $\mathrm{Ni}, \mathrm{Pb}$ and $\mathrm{Zn}$ ), the soil and biomass samples were mineralized in ultra-pure nitric acid by means of the Speed Wave MWS-2 Bergh of microwave pressure digestion system according to PN-ISO 11047:2001. The mineralized samples were analyzed by Atomic Emission Spectrometry with Inductively Coupled Plasma (ICP AES) according to PN-ISO 11042:2001.

\section{Results and Discussion}

\subsection{The Impact of Modified Fertilization on Cd} Content in the Biomass of Miscanthus giganteus $L$. and Phalaris arundinacea $L$.

Cd content in the biomass of Miscanthus giganteus L. (Fig. 1) in the first and second years of the experiment ranged from $0.0288 \mathrm{mg} \cdot \mathrm{kg}^{-1} \mathrm{~d} . \mathrm{m}$. to $0.3435 \mathrm{mg} \cdot \mathrm{kg}^{-1}$ d.m. In the first year of the experiment, adding both sewage sludge after industrial treatment (OJ) and municipal treatment (OW) contributed to increased accumulation of $\mathrm{Cd}$ by biomass of Miscanthus giganteus 


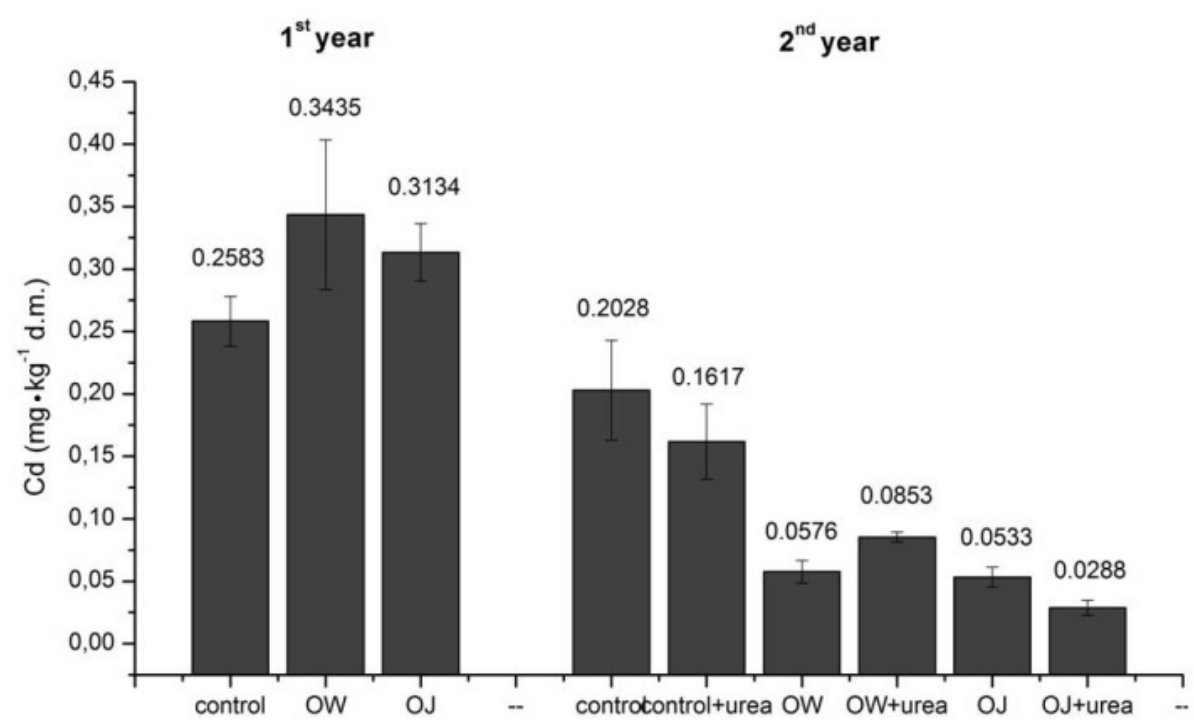

Miscanthus giganteus $\mathrm{L}$.

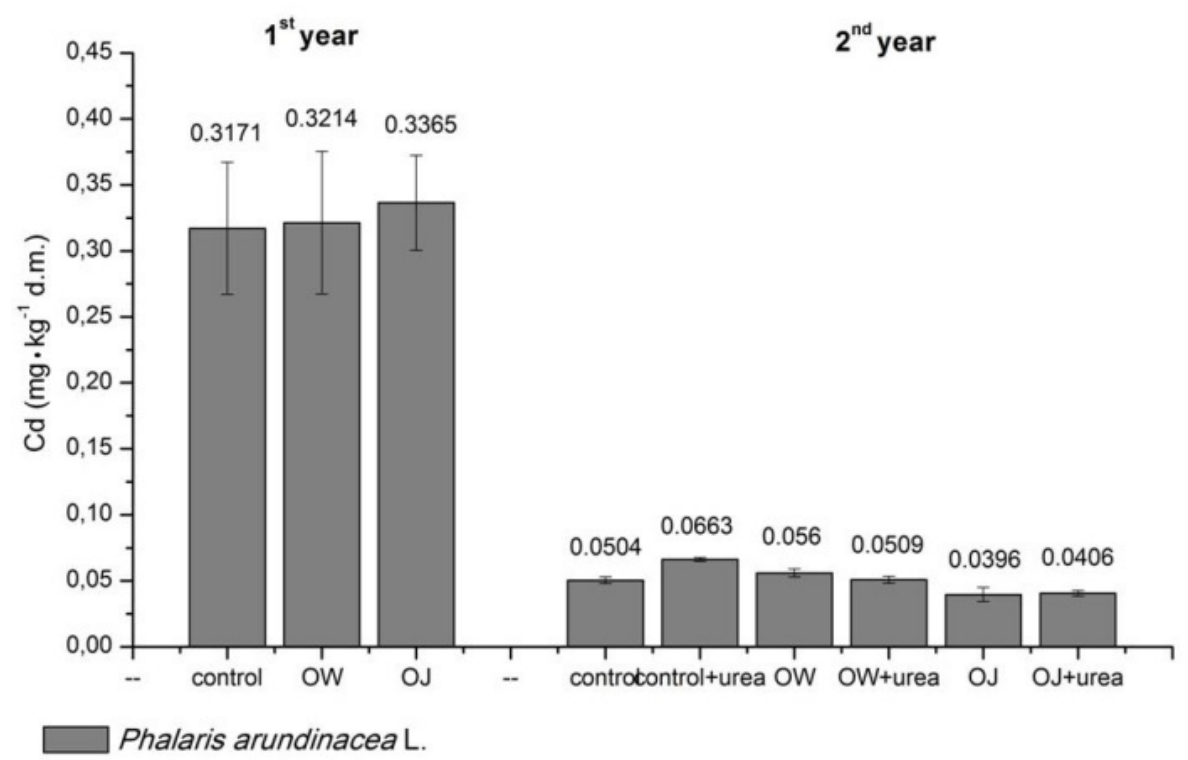

Fig. 1 Content of $\mathrm{Cd}$ in Miscanthus giganteus $\mathrm{L}$. and Phalaris arundinacea $\mathrm{L}$. biomass.

L.. Furthermore, a decreased $\mathrm{Cd}$ concentration in the biomass was observed in the second year compared to the first year of the experiment. In all combinations of fertilization, $\mathrm{Cd}$ concentration was lower in comparison to the control. Modification of organic with mineral fertilization does not have a direct effect on the accumulation of $\mathrm{Cd}$ by Miscanthus giganteus L.. The combination of OW + urea yielded an increase in the concentration of $\mathrm{Cd}$ while the combination of
$\mathrm{OJ}+$ urea caused a decline in this value.

The concentration of $\mathrm{Cd}$ in the biomass of reed canary grass (Fig. 1) within the two years of the experiment ranged from $0.0396 \mathrm{mg} \cdot \mathrm{kg}^{-1} \mathrm{~d} . \mathrm{m}$. to $0.3365 \mathrm{mg} \cdot \mathrm{kg}^{-1} \mathrm{~d} . \mathrm{m}$. In the first year of the process, addition of industrial sewage sludge (OJ) resulted in an increase in the accumulation of $\mathrm{Cd}$ in biomass by reed canary grass while fertilizer in the form of municipal sewage sludge (OW) did not cause a 
significant increase. In the second year of the experiment, a significant decrease in the concentration of $\mathrm{Cd}$ was observed in the biomass of reed canary grass compared to the first year. However, it was found that modification of organic with mineral fertilization contributed substantially to the absorption of $\mathrm{Cd}$ in the biomass of reed canary grass.

The addition of sewage sludge to soils contaminated with heavy metals causes a decrease in the concentration of bioavailable forms of $\mathrm{Zn}$ and $\mathrm{Cd}$ [21]. However, the present study did not confirm this effect - the addition of sewage sludge into the soil increased the concentration of Cd compared with the non-fertilized soil. In addition, the literature gives inconclusive relationship between the availability of metals to plants and the degree of contamination by soil. Some researchers describe the close relationship among these characteristics, while others show a correlation between the total content of heavy metals in soil and the amount collected by plants [22].

The results show that the capability of accumulation of $\mathrm{Cd}$ in both Miscanthus giganteus L. and reed canary grass is comparable. Literature data show that the aerial parts of Miscanthus giganteus L. accumulate the largest quantities of $\mathrm{Cd}[13,23]$, and, in the case of reed canary grass, the removal of $\mathrm{Cd}$ is average [14].

\subsection{The Impact of Modified Fertilization on $\mathrm{Ni}$} Content in the Biomass of Miscanthus giganteus $L$. and Phalaris arundinacea $L$.

The Ni content in the biomass of Miscanthus giganteus (Fig. 2) ranged from $0.7331 \mathrm{mg} \cdot \mathrm{kg}^{-1} \mathrm{~d} . \mathrm{m}$. to $4.98 \mathrm{mg} \cdot \mathrm{kg}^{-1}$ d.m.. In the first year of the experiment, organic fertilizing with municipal and industrial sewage sludge resulted in a reduction in $\mathrm{Ni}$ accumulation in the biomass of Miscanthus giganteus L.. A more substantial decrease compared to the control was observed after fertilization with the industrial sludge. In the second year of the experiment, the Ni content in the biomass of Miscanthus giganteus
L. was lower than in the first year of the experiment. However, modification of fertilizer (organic + mineral) did not have an effect on the accumulation of $\mathrm{Ni}$ by biomass of Miscanthus giganteus L.. A decrease in the concentration of $\mathrm{Ni}$ was observed in the combination of $\mathrm{OW}+$ urea while the combination of $\mathrm{OJ}+$ urea resulted in an increase in the $\mathrm{Ni}$ content in the biomass of Miscanthus giganteus L..

The concentration of $\mathrm{Ni}$ in the biomass of reed canary grass (Fig. 2) ranged from $0.8566 \mathrm{mg} \cdot \mathrm{kg}^{-1} \mathrm{~d} . \mathrm{m}$. to $3.76 \mathrm{mg} \cdot \mathrm{kg}^{-1} \mathrm{~d} . \mathrm{m}$. for the two years of the experiment. Fertilization of reed canary grass with municipal sewage sludge in the first year resulted in elevated concentrations of $\mathrm{Ni}$ in the biomass, while addition of the industrial sludge caused a decrease in the concentration of $\mathrm{Ni}$ in the reed canary grass biomass. In the second year of the experiment, a decrease in the concentration of $\mathrm{Ni}$ in the biomass of reed canary grass after modified fertilization was found, both for the combination of $\mathrm{OW}+$ urea or in the combination of $\mathrm{OJ}+$ urea.

In general, the addition of organic matter to the soil causes immobilization of metals through sorption. This consequently leads to a reduced content of free metal ions that can be absorbed by plants [24, 25]. The present study confirmed these observations for Ni. The addition of sewage sludge to the soil with Miscanthus giganteus L. caused a more intensive sorption of $\mathrm{Ni}$ and reduced $\mathrm{Ni}$ accumulation in the first year of the experiment. In a study on energy crops, Yelena [13] demonstrated that Miscanthus giganteus L.' roots accumulate the largest amount of Ni. This study found that Miscanthus giganteus L. and reed canary remove $\mathrm{Ni}$ from the soil to a similar extent.

3.3 The Impact of Modified Fertilization on $\mathrm{Zn}$ Content in the Biomass of Miscanthus giganteus L. and Phalaris arundinacea $L$.

The $\mathrm{Zn}$ concentration in the biomass of Miscanthus giganteus L. (Fig. 3) during the whole process ranged 


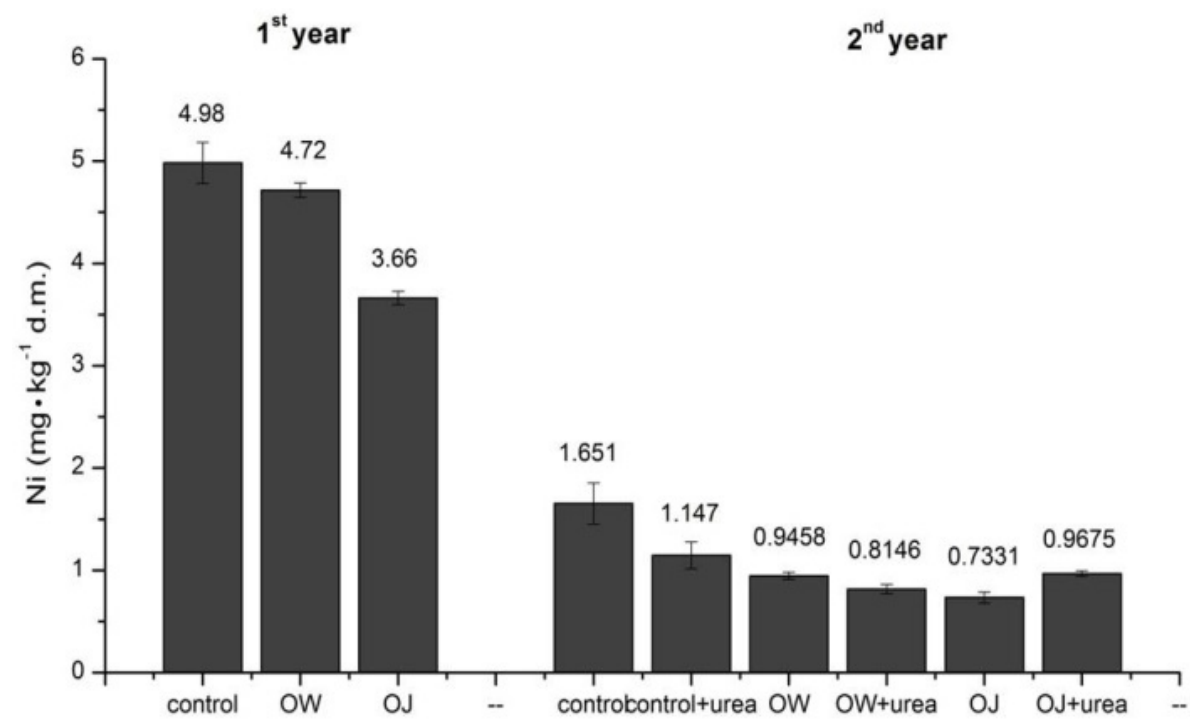

Miscanthus giganteus L.

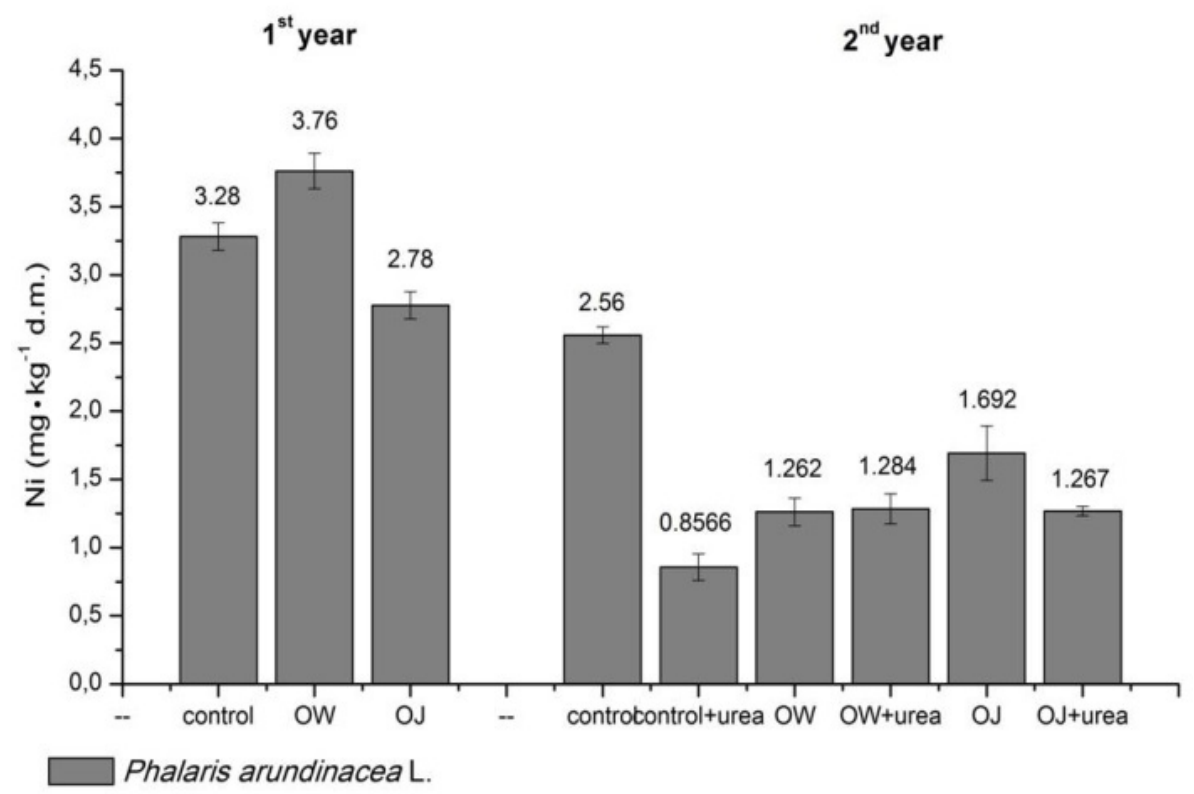

Fig. 2 Content of Ni in Miscanthus giganteus L. and Phalaris arundinacea L. biomass.

from $6.65 \mathrm{mg} \cdot \mathrm{kg}^{-1}$ d.m. to $29.5 \mathrm{mg} \cdot \mathrm{kg}^{-1}$ d.m.. In the first year of the experiment, addition of municipal sewage sludge contributed to increased accumulation of $\mathrm{Zn}$ in the Miscanthus giganteus L. biomass, while the industrial sludge caused a reduction in the concentration of $\mathrm{Zn}$ in the biomass. In the second year of the experiment, varied concentrations of $\mathrm{Zn}$ in the biomass of Miscanthus giganteus L. were observed.
However, it can be concluded that the modification of fertilizer (organic + mineral) adversely affects the capability of Miscanthus giganteus L. to accumulate $\mathrm{Zn}$.

The $\mathrm{Zn}$ content in the biomass of reed canary grass was four times higher than the concentration of $\mathrm{Zn}$ in the biomass of Miscanthus giganteus L. and ranged from $30.22 \mathrm{mg} \cdot \mathrm{kg}^{-1} \mathrm{~d} . \mathrm{m}$. to $122.6 \mathrm{mg} \cdot \mathrm{kg}^{-1}$ d.m. during 


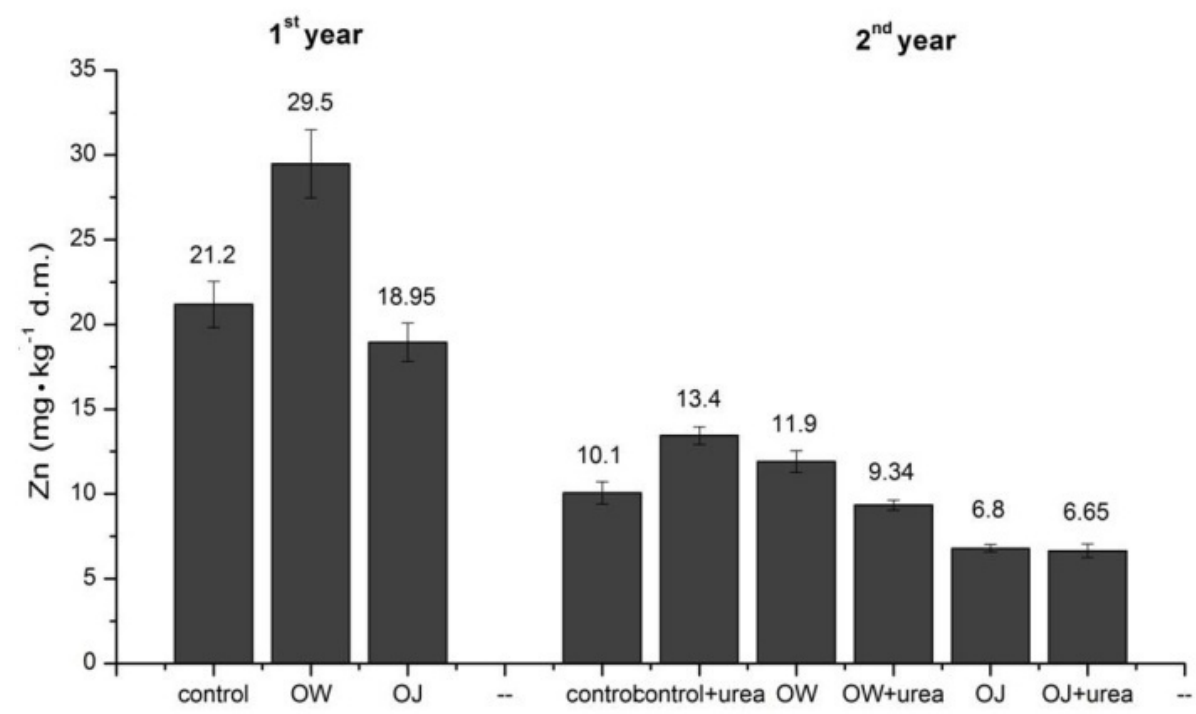

Miscanthus giganteus $\mathrm{L}$.

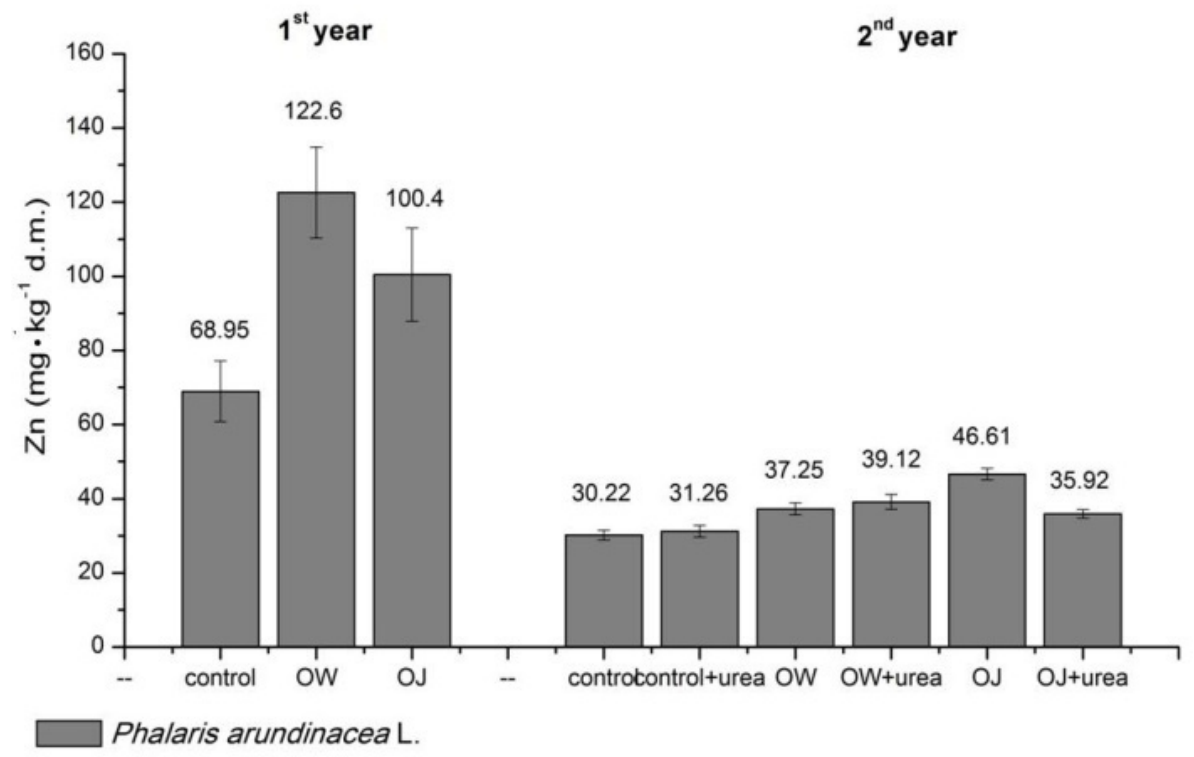

Fig. 3 Content of $\mathrm{Zn}$ in Miscanthus giganteus L. and Phalaris arundinacea L. biomass.

the two years of the experiment. The addition of sewage sludge in the first year of the experiment significantly improved the accumulation of $\mathrm{Zn}$ in the biomass of reed canary grass. However, similar to Miscanthus giganteus L., fertilization with the municipal sewage sludge had a more substantial effect. In the second year of the experiment, fertilizing with organic fertilizers of municipal sewage sludge continued to stimulate accumulation of $\mathrm{Zn}$ in reed canary grass. However, the modification of organic with mineral fertilization does not have a direct beneficial effect on $\mathrm{Zn}$ accumulation in the biomass of canary grass. An insignificant increase in the concentration of $\mathrm{Zn}$ in the biomass was observed for the combination of $\mathrm{OW}+$ urea while the combination of $\mathrm{OJ}+$ urea caused a decline in this value.

$\mathrm{Zn}$ is easily absorbed by plants but the degree of the accumulation of this element depends on the type of 
plant and even its species [26]. This study demonstrated that reed canary grass exhibits a greater capability of accumulation of $\mathrm{Zn}$ in its tissues compared to Miscanthus giganteus L.. This is confirmed by Baryła [14], who demonstrated that reed canary grass is best suited for treatment of soils contaminated with $\mathrm{Zn}$ as it accumulates this element in the largest content.

\section{Conclusions}

Modified fertilization has an impact on the quality of biomass energy crops, but it depends on the type of a plant and a heavy metal.

The growing season of plants had an effect on metal accumulation by the biomass of Miscanthus giganteus L. and reed canary grass. It was demonstrated that, compared to the first year of cultivation, plants showed a lower capability of accumulation of $\mathrm{Zn}, \mathrm{Ni}$ and $\mathrm{Cd}$ in the second year of growing.

It was observed that the accumulation of $\mathrm{Zn}$ in the biomass of Miscanthus giganteus L. and reed canary grass depends on a plant species. Higher capability of $\mathrm{Zn}$ accumulation was found for reed canary grass.

The type of fertilizer added and its modification influenced the accumulation of $\mathrm{Ni}$ in the reed canary grass and Miscanthus giganteus L. biomass and $\mathrm{Cd}$ in the biomass of Miscanthus giganteus L..

No significant effect of modified fertilization on accumulation of $\mathrm{Cd}$ was found in the biomass of reed canary grass.

\section{Acknowledgments}

The study was supported by an internal grant in the Czestochowa University of Technology BS/PB-401-304/11.

The author, Karolina Rosikon, received the grant within the project DoktoRIS-Scholarship program for innovative Silesia, co-financed by the European Union under the European Social Fund.

\section{References}

[1] Ali, H., Khan, E., and Sajad, M. A. 2013.
"Phytoremediation of Heavy Metals-Concepts and Applications." Chemosphere 91: 869-881.

[2] Khan, S., Hesham, A. E. L., Qiao, M., Rehman, S., and $\mathrm{He}$, J. Z. 2010. "Effects of $\mathrm{Cd}$ and $\mathrm{Pb}$ on Soil Microbial Community Structure and Activities." Environ. Sci. Pollut. Res. 17: 288-296.

[3] Sheoran, V., Sheoran, A., and Poonia, P. 2011. "Role of Hyper Accumulators in Phytoextraction of Metals from Contaminated Mining Sites: A Review." Crit. Rev. Environ. Sci. Technol. 41: 168-214.

[4] EPA. 2000. Introduction to Phytoremediation. U.S.: Environmental Protection Agency.

[5] Dushenkov, V., Kumar, P. B., Motto, H., and Raskin, I. 1995. "Rhizofiltration: The Use of Plants to Remove Heavy Metals from Aquaeous Streams." Environ. Sci. Technol. 29: 1239-1245.

[6] Pilon-Smits, E., and Pilon, M. 2002. "Phytoremediation of Metals Using Transgenic Plants." Crit. Rev. Plant Sci. 21: 439-456.

[7] Pulford, I. D. and Watson, C. 2003. "Phytoremediation of Heavy Metal-Contaminated Land by Trees: A Review." Environ. Int. 29 (4): 529-540.

[8] El-Bassam, N. 1998. Energy Plant Species. London: James \& James.

[9] Greger, M., and Landberg, T. 1999. "Use of Willow in Phytoextraction.” Int. J. Phytoremed. 1: 115-123.

[10] Kościk, B. 2003. Energetic Plants. Lublin: Wyd. AR. (in Polish)

[11] Zegada-Lizarazu, W., and Monti, A. 2011. "Energy Crops in Rotation: A Review." Biomass and Bioenergy 35: 12-25.

[12] Arduini, I., Masoni, A., Mariotti, M. and Ercoli, L. 2004. "Low Cd Application Increase Miscanthus Growth and Cd Translocate." Environmental and Experimental Botany 52: 89-100.

[13] Lyubun Y. V., and Tychinin D. N. 2007. "Phytoremediation in Russia." Phytoremediation Methods and Reviews 23: 423-434.

[14] Baryła, R., Sawicka, J., Kulik, M., and Lipińska, H. 2009. "Content of Components in Some Grass Species Irrigated with Purified Sewage.” J. Elementol. 14: 5-12.

[15] Kabała, C., Chodak, T., and Szerszeń, L. 2008. "Influence of Land Use on Heavy Metals Dynamics in Soils around the Copper Smelter as Observed in 34-Year-Long Cycle of Monitoring Investigation.” Zemes Ukio Mokslai (Agricultural Sciences, Litwa) 15 (3): 8-12.

[16] Kabała, C., Karczewska, A., and Kozak, M. 2010. "The Usefulness of Energy Plants for Reclamation and Development of Degraded Soils." Zesz. Nauk. UP Wroc. Rol. XCVI 576: 97-118. (in Polish)

[17] Ociepa, A., Lach, J., and Gałczyński, Ł. 2008. "Benefits and Limitations Arising from the Development of Soils 


\section{Phalaris arundinacea L.) in Dependence on Fertilization}

Polluted by Heavy Metals Under the Crops of Industrial." In Proceedings of Ecopole 2: 231-235. (in Polish)

[18] Gostomczyk, W. 2008. "Economic and Legal Problems Creating of Market of Renewable Energy Recourse." Zesz. Nauk. Instytutu Ekonomii I Zarzadzania 2: 39-49. (in Polish)

[19] Kacprzak, M., Ociepa, A., and Bień, J. 2010. "The Influence of Soil Fertilization on the Amounts of Ashes and Contents of Heavy Metals in Biomass Ashes." Archivum Combustion 30 (3): 125-131.

[20] Karczewska, A., and Kabała, C. 2005. Methods of Laboratory Analysis of Soils and Plants, Version 4. Wrocław: Akademia Rolnicza We Wrocławiu. (in Polish)

[21] Kacprzak, M., and Grobelak, A. 2011. "The Effect of Sewage Sludge Varied Doses on $\mathrm{Cd}$, Zn, Pbphytostabilization.” Inż. Ekol. 25: 99-109. (in Polish)
[22] Niemyska-Łukaszczuk, J., Miechowska, A., Mazurek, R., and Sołek-Padwika, K. 1998. "The Effect of Soil pH on the Content of $\mathrm{Zn}, \mathrm{Pb}, \mathrm{Ni}, \mathrm{Cd}$ in Plants Selected Grassland Pogorze Wielickieand Podhale." Zesz. Probl. Post Nauk. 456: 421-426. (in Polish)

[23] Sawicki, B., and Kościk, K. 2003. Grass and Grasslands, Energy Crops. Lublin: WAR. (in Polish)

[24] Kacprzak, M. 2013. Phytoremediation of Soils Contaminated with Heavy Metals. Częstochowa: Wyd. Politechniki Częstochowskiej. (in Polish)

[25] Kwiatkowska, J. 2007. "Evaluation of Brown Coal as an Effective Skurce of Organic Matter in Anthropologically Transformer Soils.” Inż. Ochr. Środ. 10 (1): 71-85. (in Polish)

[26] Kabata-Pendias, A., and Pendias, A. 1999. Biogeochemistry of Trace Elements. Warsaw, Poland: PWN. 